DOI: 10.20472/IAC.2020.054.012

\title{
TIGIST GEBREHIWOT
}

University of South Africa, Pretoria, South Africa

\section{THE MYTH OF GENDER PARTICIPATION IN AFRICAN ECONOMY}

\begin{abstract}
:
According to the latest, available data women are the majority in Africa and overrepresented in the informal economy. Sadly, in the formal sector women are less likely to participate, this range from women $63 \%$ to men $94 \%$ and why?

This paper captures women participation in Africa's economy and ask an important fundamental question that how is going to Africa to achieve the 2030 Agenda for sustainable development. It is a particular importance for this paper is Goal 5 of the Agenda in attaining gender equality. This paper hopes to engage with a global audience interested in women's economic empowerment in finding a mechanism to narrow the gap.

This is significant because there are so many gifted and talented women living undeserved lives in Africa because they are confined by restrictions imposed upon them by culture, tradition and the law. It is also because the bases of the world economy are men dominated and continue benefited majority men and need to be addressed.

This paper will offer a comprehensive assessment and critical perspective of the importance of women participation in globalised Africa's economy in realizing the sustainable development agenda.
\end{abstract}

\section{Keywords:}

Gender, Economy, Africa, Sustainable Development, Global

JEL Classification: A13, B54, D31 


\section{Introduction}

This study will offer a comprehensive assessment and critical perspective on the level of women participation in the African economy. In support of this argument selected African countries on their commitment to the issue of gender and economic empowerment will be discussed.

The objective is to create a reasonable observation of the effect of policy preparation and implementation on gender-sensitive issues in Africa. The study further, explore the changing landscape of the African economy and factors that limiting African women both from the rural and urban area from progressing in the economy. The study intends to find the most appropriate contribution to be made in this regard.

Africa is the fastest growing economy with an estimated gross domestic product (GDP) of $\$ 3.4$ trillion. ${ }^{1}$ Recently the continent paving away and launched the biggest continental free trade agreements to boost intra-regional trade and strengthening supply chains and spreading expertise. ${ }^{2}$ The preamble of the African continental trade agreement provides that 'the importance of international security, democracy, human rights, gender equality and the rule of law, for the development of international trade and economic cooperation'. ${ }^{3}$ Furthermore, Article 3(e) of the agreement provides the importance of promotion of gender equality. However, there is little mention of the national implementation strategy in ensuring women of the continent to be equally beneficial from this agreement. ${ }^{4}$

African women are far more disadvantages with inadequate representation in the key economic positions. This is because like the rest of the world the bases of African economy are men dominated and continue benefited men. Sadly, there are so many gifted and talented women living undeserved lives in Africa because they are confined by restrictions imposed upon them by culture and tradition.

\footnotetext{
${ }^{1}$ World Economic Forum How Africa's free-trade zone will provide an economic (July 2019), available at boomhttps://www.weforum.org/agenda/2019/07/africas-free-trade-zoneeconomic-boom/ (accessed 13 February 2020).

2. World Economic Forum How Africa's free-trade zone will provide an economic (July 2019).

${ }^{3}$ African Union Agreement Establishing the African Continetal Free Trade Area (2019) https://au.int/sites/default/files/treaties/36437-treatyconsolidated text on cfta - en.pdf (accessed 22 May 2020).

${ }^{4}$ United Nations Economic Commion for Africa ( February 2020) Gender mainstreaming in African Continental Free Trade Area national implementation strategies available at https://www.uneca.org/publications/gendermainstreaming-african-continental-free-trade-area-national-implementation (accessed 18 May 2020).
} 
In 2015 the world leaders including African leaders vow to implement gender equality and empowerment of all women and girls in their respective countries. ${ }^{5}$ However, in 2019 Global Gender Gap Index suggested that 108 years are needed to close the global gender gap, ${ }^{6}$ this is hostile for women to be expected to wait this long for equal participation in the economy.

Gender representation in the strategic position still shows some deficient throughout the continent. Although there is a fraction of improvement of women participation in some member countries, that is not necessarily sufficient, considering the women population in Africa are the majority.

Women employability in Africa is $50 \%$ chance compared to men $77 \%$ chance for the same rank in the formal sector, ${ }^{7}$ but women over-represented in the informal sector. ${ }^{8}$ The informal economy usually associated with poverty and low pay and the women forced to be trapped in the cycle of poverty.

Acknowledging the importance of harnessing of Africa's human resource should be the at most important in unlocking the overlooked and underutilise human capital that lies in the hands of African women is a comparative advantage to continue the momentum of economic growth.

\section{Gender dimension in the African economy}

Women are over half of the growing African population ${ }^{9}$ and it could be a strategic move to increase the number of women participating in the economy to achieve the continental and international development agenda. In 2018 the World Economic Forum suggested that African women are underutilised in the economy that they could be valuable in addressing development challenges throughout the continent. ${ }^{10}$

\footnotetext{
5 United Nation Transforming our world: the 2030 Agenda for Sustainable Development (2015), available at https://sustainabledevelopment.un.org/post2015/transformingourworld (accessed 17 February 2020).

${ }^{6}$ World Economic Forum 'How to beat gender stereotypes: learn, speak up and react' ( Mach 2019), available at https://www.weforum.org/agenda/2019/03/beat-gender-stereotypes-learnspeak-up-and-react/ (accessed 13 February 2020).

7 United Nation The worlds women (2015) available at https://www.unstats.un.org/unsd/gender/chapter4/chapter4.html (accessed 06 November 2018).

8 The worlds women (2015).

${ }^{9}$ Reines Why women hold the keys to Africa's future (19 March 2018), Available at https://www.weforum.org/agenda/2018/03/why-women-hold-thekeys-to-africas-future/ (accessed 9 March 2020).

10 Reines Why women hold the keys to Africa's future (19 March 2018)
} 
For the last decade, the African economy is growing but African women have not been yet benefited from the economic expansion in various sectors. The recent report by the African Development Bank the African economic growth expected to pick up to 3.9 per cent and 4.1 per cent in 2021. ${ }^{11}$ However, it is reported that economic growth is not inclusive. ${ }^{12}$ In this regard, there is a need for structural change that aim a more gender-inclusive economy.

For Africa to create a more balanced, inclusive and sustainable economic growth, the government should remove all forms of institutional, cultural and traditional discriminatory laws and norms. It is not all without improvement and encouraging to see a few member states in Africa shows relatively gender inclusion in the political sphere. The few African countries made progress in the political sphere, Rwanda 61.3 per cent, ${ }^{13}$ Ethiopian Cabinet member 50 Per cent and Ministerial position 50 per cent ${ }^{14}$, Namibia 46.2 per cent Cabinet Member, South Africa 42.7 per cent and Senegal 41.1 Per cent Cabinet Member. ${ }^{15}$ But still, in most African countries, there is a low proportion in the appointment of women in a key Ministerial position, ${ }^{16}$ and the key economic positions and change have persued.

The challenge in gender disparity in the economy is not unique to Africa but it is widely acknowledged that global skilled population the wage gap between men and women education and skills is higher for men than women. The study shows that the gap wages women earn is 60 per cent to 75 per cent of men's wages. ${ }^{17}$

\footnotetext{
${ }^{11}$ African Development Bank 'African Economic Outlook 2020: Developing Africa's workforce for the future' (2020), available at https://www.afdb.org/en/knowledge/publications/african-economic-outlook (accessed 20 February 2020).

12 African Economic Outlook (2020)

13 World Economic Forum 'These countries have the most women in parliament' available, https://www.weforum.org/agenda/2019/02/chart-of-the-day-thesecountries-have-the-most-women-in-parliament/ (accessed 20 February 2020).

14 Dahir 'Ethiopia's new 50\% women cabinet isn't just bold-it's smart' (16 October 2018), available at

https://qz.com/africa/1426110/ethiopias-new-cabinet-is-50-women/ (accessed 20 February 2020).

15 These countries have the most women in parliament (2020).

${ }^{16}$ These countries have the most women in parliament' available (2019).

17 UN Women Facts and Figures: Economic Empowerment Benefits of economic empowerment www.unwomen.org/en/what-we-do/economicempowerment/facts-and-figures, see, Organization for Economic Cooperation and Development (OECD), Gender Equality in Education, Employment and Entrepreneurship: Final Report to the MCM 2012. http://www.oecd.org/employment/50423364.pdf. p. 17. See also, Klasen, and Lamanna (2009), "The impact of gender inequality in education and employment on economic growth: New evidence for a panel of countries," Feminist Economics, 15: 3, pp. 91-132 (as retrieved from UN Women, Progress of the World's Women 2015-2016: Transforming economies, realizing rights Chapter 4, p. 199).
} 
Women continuously encounter challenges advancing in the economy.

Structural change in the African economy is a key component to ensure equal participation of women in various sector. Agriculture is the main key economic driver in most of the African countries but the gender disparity in the agriculture sector is huge despite women making up the majority of farmworkers, their stake share of land ownership far less than men. Ownership of land an average only 15-20 per cent of landholders are women, and they receive less than $10 \%$ of available credit. ${ }^{18}$ As of now in most parts of the world women have less access to financial institutions and saving mechanism, as far as 55\% of men report having an account at a financial institution only $47 \%$ of women do worldwide. ${ }^{19}$ This gap is even wider among lower-income economies like Africa.

The lack of access to financial services is only one of the factors putting women impossible situation to progress in the economy. It is also lack of domestic laws protecting women from domestic violence, equal inheritance rights for daughters and sons, lack of flexible working conditions that puts more time constraints due to extra household works activities women expected to do and in some part of Africa still there is customary law that doesn't acknowledge women's rights to own land. The problem mostly lies in the gap created between African statutory and customary laws that left women vulnerable to discrimination.

For example, Botswana a country situated in the southern part of Africa, it's customary law provided that if a woman married under traditional law are considered legally minor and incapable enter into any legally bounding contract or access to bank loan without the consent of her husband. ${ }^{20}$ This is contrary to the 'African Charter on Human and Rights (1981)' Article 18(3) provided that all African state eradicate every discriminatory law against women. ${ }^{21}$ In 2003 further, the African Union adopted the Maputo protocol in clarifying the provision which was ambiguous on the

\footnotetext{
18 Sihlobo and Setou 'Land matters to women and they should be involved in decision-making' (10 August 20190, available at https://www.iol.co.za/news/opinion/land-matters-to-women-and-they-shouldbe-involved-in-decision-making-30590627 (accessed 19 February 2020).

19 UN Women Facts and Figures: Economic Empowerment Benefits of economic empowerment (2012).

${ }^{20}$ Food and Agriculture Organisation 'Gender and Land Rights Database' available at http://www.fao.org/gender-landrightsdatabase/country-profiles/countries-list/customary-law/en/?country_iso3=BWA (accessed 5 March 2020).

${ }_{21}$ African Union 'African Charter on Human and Peoples' Rights' https://au.int/en/treaties/african-charter-human-and-peoples-rights (accessed 5 March 2020).
} 
charter back in 1981, set a clear message on the women's rights. The protocol stressed out on the obligation of the member's state to eliminate all forms of discrimination and violence against women and the inclusion of women in the formulation of cultural value. In its preamble paragraph two states that:

"women shall enjoy based on equality with men the same rights and respect for their dignity and contribute to the preservation of those African cultural value that is positive and is based on the principles of equality, dignity, justice and democracy."22

The African customary law often neglects the issue of the inclusion of women in cultural value. It is still widespread practice particularly, in the rural part of most African countries men have the right to chastise their wives, customary law does not specifically prohibit violence against women. ${ }^{23}$ Regardless of the African Union Charter, Protocol, and effort by the united nations as provided on the conventions on the elimination of all forms of discrimination against women, ${ }^{24}$ still women are marginalised in some part of Africa on the bases of their gender cannot even inherit land if there is an existing male family member of the husband. ${ }^{25}$ For example, in a rural part of Nigeria 80 per cent of land dispute settled in terms of customary law despite the contrary to the legislative and constitutional legal framework existed in the country that allows women's equal rights. ${ }^{26}$ In practice, there is a huge gap to implement the continental and global legal instrument in individual jurisdictions. Customary law that promotes genderbased socio-economic structure that resulted in millions of African women remain dis-empowered shouldn't be tolerated.

In terms of African Customary law at large land and property rights of women are far less have been recognised in the rural part of

\footnotetext{
${ }^{22}$ African Union ' Protocol to the African Charter on human and people's rights on the rights of woman in Africa (2003), available at https://www.un.org/en/africa/osaa/pdf/au/protocol_rights_women_africa_2003. pdf (accessed 5 March 2020).

${ }^{23}$ Food and Agriculture Organisation 'Gender and Land Rights

Database' available at http://www.fao.org/gender-landrights-

database/country-profiles/countries-list/customary-law/en/?country_iso3=BWA (accessed 5 March 2020).

24 United Nations entity for gender equality and the empowerment of women (2009), available at

https://www.un.org/womenwatch/daw/cedaw/cedaw.htm (accessed 5 March 2020).

${ }^{25}$ International Human Rights Law Group 'Women's inheritance rights in Africa initiative'(2017), available at

http://www.hrlawgroup.org/initiatives/inheritance_rights/ (accessed 20 February 2020).

${ }^{26}$ Women's inheritance rights in Africa initiative(2017).
} 
Africa. ${ }^{27}$ In this regard, there is an improvement in South Africa on women's rights to inherit the land. In the matter heard in the South African Court ('The V Khalyelisha Magistrate and Others (CCT 49/03) [2004] ZACC 17; 2005 (1) SA 580 (CC); 2005 (1) BCLR 1 (CC) (15 October 2004). ${ }^{28}$ The constitutional court held that the customary law that excludes women from the inheritance of land was declared unconstitutional. ${ }^{29}$ Following the court order in 2009, the legislature enacted the 'Reform of Customary Law of Succession and Regulation of Related Matter Act 11 of 2009 (the "reform" Act), came into effect 20 September 2010 that allow women's equal rights to inherit the land. ${ }^{30}$ The constitutional court further reiterates that the respect and recognition of fundamental rights enshrined in the South Africa constitution (1996) must be respected. ${ }^{31}$ It also explained the principle and the disputed sections of customary law doesn't acknowledge women's rights and further infringe upon the fundamental rights to equality and human dignity. ${ }^{32}$ Therefore, customary law in South Africa is subject to the constitutional review, if it contravenes the fundamental rights of the constitution and can be declared unconstitutional. It is, therefore, countries in other parts of Africa should adopt a similar measure to promote gender equality.

In summary, the increased ratification of protocol and convention on the rights of women in Africa is not enough unless it supported by government strategy for implementation. It is important to address the issue of denial of the right to property, right to access finance and gender-based violence are the main root cause that hinders women from participating in the growing African economy. This can be addressed through the implementation of legal and non-legal structures that enforce a pro-women agenda.

In upholding the Sustainable Development Goal of 2030 of the United Nations, the Africa Union charter and protocol, African leader should take urgent and appropriate measure to enable the legal discourse assessing the level of discrimination, unfair social, economic and cultural norms in the national context to inform the

\footnotetext{
27 Shibi V Sithole and others International Human Rights Law Group ' Women's inheritance rights in Africa initiative'(2017).

28 South African Legal Information institute 'Bhe and Others v

Magistrate, Khayelitsha and Others; Shibi v Sithole and Others; SA Human Rights Commission and Another v President of the RSA and Another 2005 (1) BCLR 1 (CC)' available at

http://www.saflii.org/za/cases/ZACC/2004/17.html (accessed 20

February 2020).

${ }^{29}$ Bhe and Others v Magistrate (2005) (1) BCLR 1 (CC).

30 Parliament of the Republic of South Africa 'Reform of Customary Law of Succession and Regulation of related Matter Act 11of 2009', available at https://www.justice.gov.za/legislation/acts/2009-011.pdf (accessed 20 February 2020).

${ }^{31}$ Bhe V Khalyelisha Magistrate and Others (CCT 49/03)

32 Bhe V Khalyelisha Magistrate and Others (CCT 49/03)
} 
design and implement the laws and policies aiming to eliminate factors hindering women from progressing, in the economic, social and political spheres.

\section{Economic Governance in Africa}

It is mostly African countries budget spending always influenced by government political priorities in the distribution of public finance. Leaders could utilise its budget, to address gender inequality within the national development framework. This means that empowering women and closing gender gaps is a key to implement the provision of the protocol to the 'African charter on human and people's rights' on the rights of women and achieving goal 5 of the United Nations 2030 Agenda for sustainable development. Both protocol and 2030 Agenda provides an element to strength good economic governance. This is crucial to ensuring the resource shared equitably among society irrespective of gender and race.

For sustainable economic growth, African leaders should consider inclusive budget distribution and integrate gender components in the planning and coordination of the various state organs to ensure the proper allocation of resource. Despite the significant increase in women representation, yet countries failed to eliminate the gender gap. Women participation in the economy is crucial in drawing the overlooked talent and hidden resource women acquire to grow the economy even further. This requires a strong commitment from leaders to eliminate the existing structural discrimination and promote equal rights to women.

Although gender disparity is the global problem, it is widened in Africa. According to the study as indicated above the employability of women globally is less chance compared to men in the same rank. ${ }^{33}$ This even wider in developing countries like Africa. The majority of African women working and operating in the informal sector where the wage is low and trapped in poverty. ${ }^{34}$ This is because the informal sectors stacked in selfregulation without social support in the form of official policies and resources. Given that African women are a productive part of society with the enormous unexploited potential to contribute to the economy but limited by culture and tradition from taping the benefit available in the economy.

\footnotetext{
${ }^{33}$ UN women 'Turning promises into action: Gender equality in the 2030 Agenda for sustainable development (New York 2018).

${ }^{34}$ UN women 'Turning promises into action: Gender equality in the 2030 Agenda for sustainable development (New York 2018).
} 
Countries from the Organisation for Economic Co-operation and Development (OECD) increased women participation in their economy that brought $50 \%$ increased for the past 50 years of the countries' economy. ${ }^{35}$ This is because the available scientific study suggests that women aged 25-54 increase their labour force participation in most of the world, while that of men in the same age group stagnated or declined slightly. ${ }^{36}$

It is therefore unless gender equality materialised in Africa's economy and change the mindset of society concerning male and female role rooted in culture and tradition it is impossible to achieve the goal to eradicate extreme poverty in Africa. Equal participation of gender in the economy is crucial in securing sustainable growth in the economy of a country or a company. Companies increased the number of women in the key area shown to increase organisational effectiveness, economic growth and the overall organisational performance. ${ }^{37}$ It is therefore, Africa should have a strategy to implement the developmental goal of equal participation of women in the economy.

\section{Financing and Gender equality in Africa}

Financial access in Africa to women lagging, 37\% of women access to finance compared to $48 \%$ male. ${ }^{38}$ This gap resulted mostly by lack of access to education, disproportionate unpaid caregiving burden imposed by culture and tradition, job segregation and domestic violence are some of the main root cause limiting African women progressing in the economy.

African women often overlooked as they are part of the economic force and a key to Africa's future in addressing the development challenges the continent faces. ${ }^{39}$ The already considerable gap in the economy continues to grow unless proper policy action implemented to achieve universal financial inclusion strategy for sustainable economic growth.

\footnotetext{
35 OECD 'Gender equality in education, employment and entrepreneurship: Final report to the MCM (2012) 3, available at http://www.oecd.org/employment/50423364.pdf (accessed 5 March 2020).

36 The worlds women (2015)

https://www.unstats.un.org/unsd/gender/chapter4/chapter4.html (accessed 06 November 2019).

37 Mckinsey \& Company ' Women matter: Time to accelerate ten years of insight into gender diversity (2018), available at https://www.mckinsey.com/featured-insights/gender-equality/womenmatter-ten-years-of-insights-on-gender-diversity (accessed 5 March 2020).

${ }^{38}$ Rhyne 'The Outlook for Universal Financial Access in 2020' (10 April 2019) available at https://www.centerforfinancialinclusion.org/the-

outlook-for-universal-financial-access-in-2020 (accessed 16 April 2020).

39 Reines 'Why women hold the key to Africa's future' (19 March 2018).
} 
The world bank and the various international finance corporation set a goal by 2020 to give access to financial services to the world unbanked adult. ${ }^{40}$ Although it is a well-intentioned campaign and key for sustainable economic growth it has been yet been realised. Even though gender inclusivity has not been explicitly expressed in the Universal Financial Access of 2020 agenda but is embedded in the principle of inclusivity to give access to financial service to all unbaked adults including women.

In this regard, it is pursued that the government commitment to strive toward measure to strengthen gender equality in accessing finance is to signal the right balance in achieving the goal of financial inclusion of 2020 and in building more inclusive, sustainable and inclusive economic growth.

\section{Conclusion}

Women around the world continue to encounter challenges when it comes to advancing their participation in the economy. It is an unacceptable reality that no country in the world has yet managed to eliminate the gender gap in the economy and this even worse in Africa. For Africa to achieve its target, continue to grow its economy and succeed in its development agenda it is crucial for equal participation of women. This requires the political will of the government commitment to intensify and formulate a policy that is gender-sensitive and inclusive.

It is also equally important to acknowledge the absence of sufficient opportunities for women, lack of social protection, direct and indirect discrimination should be addressed in every level of society. It is further persued to have Integrated gender-responsive systems in place in responding to each problem. In this regard, leaders should speed up the structural change of the economy that is inclusive to women and formulate a mechanism to implement the rules that promote gender equality.

The policy should also reach women in a rural area and informal sectors where the majority of women found. Often African women left behind in rural area by their male partner and forced to maintain their life and their children on their own and involve in the informal sector. Traditionally the informal sector associated with poverty. In this regard, transformation in the informal sector

\footnotetext{
40 World Bank 'UFA2020 Overview: Universal Financial Access by 2020' (1 October 2018), available at https://www.worldbank.org/en/topic/financialinclusion/brief/achieving-universalfinancial-access-by-2020 (accessed 16 April 2020).
} 
is also needed to help uplift the majority of women involved in the informal sector. For this reason, there must be clear and specific initiatives to be taken by the government for a smooth transition of informal operation to formality to curve women suffering. The initiative should include equal access to finance, trade facilitation, skill development and the protection and provision of the law should reach women in the informal sector and rural area.

As of now the intensifying race by the African leaders for job creation, usually settle for the bottom to see how they can provide lower standards, reduced wages and cheaper resources to foreign direct investors are not conducive. This has neither produced sufficient job that can help women to progress nor reduced poverty or reduce inequality, but it maintains the cycle of a historic unequal society and change has pursued.

Furthermore, the national government should continue to provide an enabling environment to support women. This should be done by considering the linkage that exists in society limiting women from progressing. Such as change mindset of society about women and eliminate all tradition and culture discrimination against women. The law should send a strong message to society against domestic violence and increasing the number of girls in school.

Also, the African government should transform the land and property legal structure particularly, those fall under traditional and customary law regime. It is important to formulate a strategy to implement women's land rights together with financial access to help women to develop the land to use it as a commodity to gain market-based efficiency.

Within the context of supporting the economic empowerment of women, the government should continue to provide a genderresponsive public financial management system to build a healthy and sustainable economic growth in the country. This needs a high level of political commitment that is based on genderconscious economic empowerment initiatives. In conclusion, the continuation of economic growth in Africa depends on the potential of a demographic dividend that can only be harnessed if women are promoted as a full economic citizen in the inclusive growth process. 


\section{Reference}

African Union Agreement Establishing the African Continental Free Trade Area (2019) available at https://au.int/sites/default/files/treaties/36437-treatyconsolidated_text_on_cfta_-_en.pdf (accessed 22 May 2020).

African Union 'Protocol to the African Charter on human and people's rights on the rights of woman in Africa (2003), available at

https://www.un.org/en/africa/osaa/pdf/au/protocol_rights_women _africa_2003.pdf (accessed 5 March 2020).

Abdi Latif Dahir 'Ethiopia's new 50\% women cabinet isn't just bold-it's smart' (16 October 2018), available at https://qz.com/africa/1426110/ethiopias-new-cabinet-is-50women/ (accessed 20 February 2020).

African Development Bank 'African Economic Outlook 2020: Developing Africa's workforce for the future' (2020), available at https://www.afdb.org/en/knowledge/publications/africaneconomic-outlook (accessed 20 February 20202).

Elisabeth Rhyne The Outlook for Universal Financial Access in 2020 (10 April 2019), available at https://www.centerforfinancialinclusion.org/the-outlook-foruniversal-financial-access-in-2020 (accessed 16 April 2020).

Food and Agriculture Organisation 'Gender and Land Rights Database' available at http://www.fao.org/gender-landrightsdatabase/country-profiles/countries-list/customarylaw/en/?country_iso3=BWA (accessed 5 March 2020).

International Human Rights Law Group 'Women's inheritance rights in Africa initiative'(2017), available at http://www.hrlawgroup.org/initiatives/inheritance_rights/ (accessed 20 February 2020).

Klasen, S. and Lamanna, F. (2009), "The impact of gender inequality in education and employment on economic growth: New evidence for a panel of countries," Feminist Economics, 15: 3, pp. 91-132 (as retrieved from UN Women, Progress of the World's Women 2015-2016: Transforming economies, realizing rights Chapter 4, p. 199).

Mckinsey \& Company ' Women matter: Time to accelerate ten years of insight into gender diversity (2018), available at 
https://www.mckinsey.com/featured-insights/genderequality/women-

matter-ten-years-of-insights-on-gender-diversity (accessed 5 March 2020).

OECD 'Gender equality in education, employment and entrepreneurship:

Final report to the MCM (2012) 3, available at http://www.oecd.org/employment/50423364.pdf (accessed 5 March 2020).

Organization for Economic Cooperation and Development (OECD), Gender Equality in Education, Employment and Entrepreneurship: Final Report to the MCM 2012, available at http://www.oecd.org/employment/50423364.pdf. p. 17 (accessed 18 February 2020).

Rara Reines 'Why women hold the keys to Africa's future' (19 March 2018), available at https://www.weforum.org/agenda/2018/03/why-women-hold-thekeys-to-africas-future/ (accessed 9 March 2020).

South African Legal Information institute 'South Africa:

Constitutional Court (2004), available at http://www.saflii.org/za/cases/ZACC/2004/17.html (accessed 20 February 2020).

United Nations Economic Commission for Africa ( February 2020) Gender mainstreaming in African Continental Free Trade Area national implementation strategies available at https://www.uneca.org/publications/gender-mainstreamingafrican-continental-free-trade-area-national-implementation (accessed 18 May 2020).

UN women 'Turning promises into action: Gender equality in the 2030 Agenda for sustainable development (New York 2018), available at http://www.unwomen.org/en/digitallibrary/publications/2018/2/gender-equality-in-the-2030-agendafor-sustainable-development-2018 (accessed 5 March 2020).

United Nations Women Facts and Figures: Economic Empowerment Benefits of economic empowerment www.unwomen.org/en/what-we-do/economicempowerment/facts-and-figures (accessed 18 February 2020).

United Nations entity for gender equality and the empowerment of women (2009), available at 
https://www.un.org/womenwatch/daw/cedaw/cedaw.htm (accessed 5 March 2020).

United Nation Transforming our world: the 2030 Agenda for Sustainable Development (2015), Available at https://sustainabledevelopment.un.org/post2015/transformingour world (accessed 5 March 2020).

Parliament of the Republic of South Africa 'Reform of Customary Law of Succession and Regulation of Related Matter Act 11 of 2009', available at https://www.justice.gov.za/legislation/acts/2009-011.pdf (accessed 20 February 2020).

Wandile Sihlobo and Peter Setou 'Land matters to women and they should be involved in decision-making' (10 August 20190, available at https://www.iol.co.za/news/opinion/land-matters-towomen-and-they-should-be-involved-in-decision-making30590627 (accessed 19 February 2020).

World Bank 'UFA2020 Overview: Universal Financial Access by 2020' (1 October 2018), available at https://www.worldbank.org/en/topic/financialinclusion/brief/achie ving-universal-financial-access-by-2020 (accessed 16 April 2020).

World Economic Forum 'How Africa's free-trade zone will provide an economic boom' (2019), available at https://www.weforum.org/agenda/2019/07/africas-free-tradezone-economic-boom/ (accessed 13 February 2020).

World Economic Forum 'These countries have the most women in parliament' available, https://www.weforum.org/agenda/2019/02/chart-of-the-daythese-countries-have-the-most-women-in-parliament/ (accessed 20 February 2020). 